\title{
Where are the boundaries of official statistics? Armenia case study
}

\author{
Stepan Mnatsakanyan and Anahit Safyan* \\ Statistical Committee of the Republic of Armenia (Armstat), Yerevan, 0010, Republic of Armenia
}

\begin{abstract}
Given the increasing impact that globalization has on modern societies, today more than ever there is a need for comprehensive and targeted information about all kinds of economic, social, environmental and other aspects that shape our daily lives. This is where official statistics as a genuine information source for political decision makers and society as a whole come into play. Nevertheless, Official Statistics are rarely produced exclusively by the National Statistical Office; it often comprises other producers whose number depends on how centralized or decentralized a National Statistical System is. Hence, one central question is how a National Statistical System can be coordinated. Where are the lines that separate Official Statistics from other providers of information and who is coordinating it?

The boundaries of official statistics are often specified by the Generic Law on Official Statistics developed jointly by the UNECE Statistics Division, UN Statistics Division, EFTA, Eurostat and experts from several countries. This paper presents legal, organizational and coordinational aspects of the National Statistical System (NSS) in Armenia. It focuses on how Armstat, the National Statistical Office of Armenia fulfills its coordination role in the NSS while also shedding some light on the bodies of statistical governance in the Republic of Armenia.
\end{abstract}

Keywords: Official Statistics, National Statistical System, law, coordination, governance

\section{Introduction}

This paper discusses the role of Official Statistics in the modern world and its legislative boundaries within the National Statistical System of Armenia as defined by the Generic Law on Official Statistics [1].

It is based on a presentation given at the 2019 ISI World Statistics Congress in Kuala Lumpur, Session IPS 071, jointly organized by the European Free Trade Association (EFTA) and the United Nations Economic Commission for Europe (UNECE), and is connected to two other presentations also given at this occasion [2]. However, whereas those contributions addressed the topic of the boundaries of National Statistical Systems in a more general perspective, this paper focuses on a specific country perspective.

\footnotetext{
Corresponding author: Anahit Safyan, Statistical Committee of the Republic of Armenia (Armstat), Government Building 3, Republic ave., Yerevan, 0010, Republic of Armenia. Tel.: +374 91510286 ; E-mail: safyan@armstat.am.
}

Characterized by global challenges such as the spread of digital technologies and the information society, it is a fast changing world. Official Statistics have to develop and adapt as a reaction to those challenges. There is an international consensus that Official Statistics are a cornerstone of an open society [3].

Due to increasing globalization in all areas of social life, today more than ever, there is the need for more complete and targeted information about the functioning and efficient organization of public life. In societies consisting of millions of people there is no alternative to Official Statistics as an impartial, high-quality source of information.

Official Statistics are developed, produced and disseminated in accordance with international references, such as the UN Fundamental Principles of Official Statistics [4]. The numerical expressions of the essential phenomena of public life are reflected by the statistical programs that the producers of Official Statistics regularly publish in a transparent manner.

Official Statistics is an indispensable source of information, providing the public with data about the eco- 
nomic, demographic, social and environmental situation [5]. In fact, the mission of Official Statistics, often produced by various administrative bodies, including the National Statistical Offices, is the general provision of unbiased and comparable information to the society at large. All producers of Official Statistics make up the National Statistical System (NSS). In order to carry out the task of producing and disseminating unbiased statistics, National Statistical Systems need to have a strong legal and institutional setting to guarantee their independence, integrity and accountability and assure data quality and data security according to the highest international standards. The legal basis also provides the basis for the coordination of the different producers of Official Statistics by the National Statistical Office.

As the environment of official statistics is changing rapidly, statistical offices need a legislative and institutional infrastructure that allows for the development and modernization of production tools and organizational models, using new non-traditional data sources and advanced information and communication technologies. The increasing availability of all kinds of data challenges the exclusive position of Official Statistics to serve high quality and timely statistics. In order to meet all those challenges coming with modern data ecosystems, a new statistical legislation is needed that grants Official Statistics access to various data sources.

Recently, the international community of producers of Official Statistics has raised the necessity to reinforce legal frameworks in order to guarantee the independence of statistical systems and to gain wide access to existing information sources [6].

Statistical legislation is a key condition for an efficient statistical organization and the production of quality official statistics that meets the statistics users' changing needs. As an instrument for modernization, a modern legal framework enables a more flexible strategic development of official statistics in order to allow the use of open data, new data sources and technologies as well as non-traditional data sources such as big data, geospatial information, etc.

A modern statistical legislation supports the further strengthening of National Statistical Systems and the modernizing of Official Statistics. It supports the comparative advantage of Official Statistics while strengthening their professional and independent production, based on scientific methods, rigorous quality criteria, and the Fundamental Principles of Official Statistics. In this respect the model of the Generic Law on Official Statistics [1] should become a national standard that can be adapted to legislative peculiarities, taking into account countries constitutional order, culture, traditions, etc.

\section{The legal basis of Armenian Official Statistics}

The new Armenian Law on Official Statistics [7] entered into force on 9 April 2018. It is based fully on the model of the Generic Law on Official Statistics [1]. As opposed to the former statistical law ${ }^{1}-$ which did not define the National Statistical System, nor Official Statistics precisely but mainly regulated the work of Armstat - the new law focuses on the establishment of the National Statistical System (NSS) as the coordinated system of producers of Official Statistics. The National Statistical Office has the role of coordinating the NSS, this means all producers of Official Statistics as well as bodies providing data for the production of Official Statistics without being themselves producers of Official Statistics. The UN Fundamental Principles of Official Statistics [4] and the principles of the European Statistics Code of Practice [8] provide the organizational and production standards for Official Statistics in Armenia. Thus, the law enables closer alignment with the mentioned principles and allows for a more agile strategic development of official statistics by putting users of statistics at the center; it requires having a Public Council as a Statistical Advisory Council composed of users of statistics with advisory competences. In this way, the statistics law also enhances public trust and promotes the use of official statistics in the country. The Public Council of Users is a well-established mechanism for the representation of users, which allows them to offer advice to Armstat in the programming of statistical work or to gather feedback on user satisfaction. The Public Council ensures that the views of users are taken into account when setting priorities in the statistical program; it promotes transparency and accountability of the NSS.

\section{The National Statistical System (NSS) of Armenia}

The NSS of Armenia is a relatively centralized system, although it contains several producers of Official Statistics in Armenia as well as different data providers.

The NSS of Armenia (see Fig. 1) consists of all producers of Official Statistics and data providers (which are not considered producers of Official Statistics), including the following main producers:

\footnotetext{
${ }^{1}$ The old statistical law considered Armstat as the only produce of state statistics. Statistics produced by other public authorities were referred to as "administrative statistics".
} 


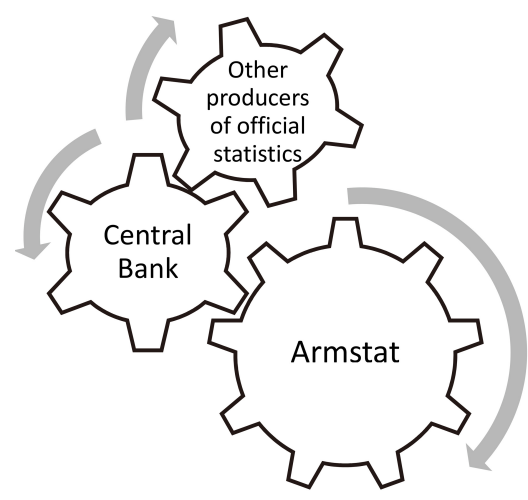

Fig. 1. NSS of Armenia.

1. Armstat, the national statistical office of Armenia as the coordinating body of the NSS of Armenia. Armstat is the main producer of Official Statistics that coordinates all activities for the development, production and dissemination of official statistics within the NSS.

2. The Central Bank of Armenia.

3. The organizational units of state and local selfgovernment bodies.

Typically, all producers of Official Statistics develop, produce and disseminate Official Statistics in accordance with the annual statistical program. They cannot be assigned responsibilities that are in contradiction with the UN Fundamental Principles [4].

The Central Bank of Armenia, as one producer of official statistics, carries out its activities related to official statistics in accordance with the Law of Armenia "On the Central Bank of Armenia", which takes into account the requirements of the UN Fundamental Principles [4].

Although not part of Official Statistics but in some ways attached to the NSS are the already mentioned administrative data providers (as far as they only provide data without producing statistics themselves): state and local self-government bodies that provide producers of official statistics with data collected for administrative purposes. Provision of administrative data by the Central Bank of Armenia is carried out in accordance with the "Law on the Central Bank of the Republic of Armenia" and the normative legal acts adopted on its basis.

The statistical law of Armenia also mentions other parties that are not directly part of the NSS but have a role to fulfill in the production of Official Statistics, such as:

1. Respondents: natural and legal persons considered as a statistical unit, including separate units in the territory of Armenia operated by foreign le- gal persons, individual entrepreneurs, households, state and local self-government bodies and state institutions without the status of legal person, that are requested to provide information about themselves and their activities, through data collection carried out by producers of official statistics.

2. Users of official statistics: natural and legal persons, state and local self-government bodies, international organizations and authorities of other countries, who receive official statistics or have access to it.

3. Advisory bodies of statistics users: Public Council of Users of Official Statistics, other advisory bodies.

\section{Armstat as the central coordinator of the NSS}

Armstat, the National Statistical Office of Armenia, is a state body implementing functions of public interest. It is independent in its activities, and financed from the state budget. Armstat carries out its activities through the Central Office in Yerevan and 11 regional agencies of statistics.

The NSS of Armenia is a relatively centralized system, which is coordinated by the Armenian National Statistical Office. Armstat produces most of the statistical products to be considered Official Statistics. The Central Bank and the Ministry of Finance are other producers of official statistics.

The legal framework for Armstat's coordination role ensures that statistics produced within the NSS meet the relevant quality standards. The main coordination goals are to avoid duplication of work, to minimize the reporting burden of respondents and to facilitate the integration of data from different sources by using internationally recognized statistical standards and methodologies.

Armstat coordinates and promotes common practices across the NSS in collaboration with other producers of official statistics.

All producers of official statistics, including the Central Bank of Armenia, use common, internationally agreed concepts, definitions, classifications and methods.

Figure 2 gives an overview of the tools and the sequence of coordination in the Armenian NSS.

Coordination instruments for the NSS are:

1) Statistical programs

A 5-year statistical program and an annual statistical program are key instruments for effective strategic 


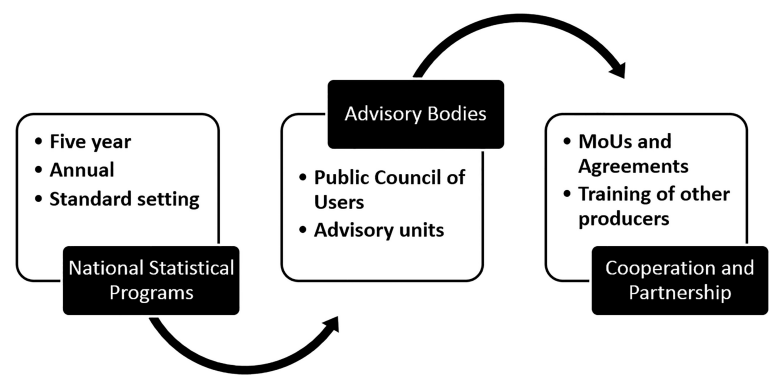

Fig. 2. Sequence of coordination mechanisms and instruments in the Armenian NSS.

and operational management and coordination of activities in the NSS. Strategic and annual programs are the main coordination instruments of the system of official statistics.

The coordination task of Armstat includes ensuring coherent terminology, setting common standards, classifications and methods, standards for metadata, supporting and advising other producers in methodological issues, and the implementation of UN Fundamental principles of Official Statistics [4] and European Statistics Code of Practice [8].

\section{2) Advisory bodies}

The Public Council of Users is the main advisory body representing the user community (not producers). It advises the NSS and is consulted during the preparation of the statistical programs and follows up on their implementation. Advisory Units are thematic user groups advising on methodological issues. The subject matter divisions of Armstat exercise the coordination of the methodology to be used in specific statistical areas. We will come back to such bodies of statistical governance further down.

3) Cooperation and partnership, leadership

Other important coordination instruments are Memoranda of Understanding (MoUs) and cooperation agreements between Armstat and administrative data owners on data delivery to Armstat and cooperation on administrative data quality. Armstat concluded a number of MoUs with the Armenian Central Bank and numerous Ministries. In this way a shared interest in working together for quality assurance and exchange of quality information is created, and the overall response burden for respondents reduced. Furthermore, Armstat provides training on the use of classifications, standards and methodologies to its partners (for example, on NACE Rev. 2 for the staff of the State Revenue Committee, on methodology of ILO 19th International Conference of Labour Statisticians for the staff of the Ministry of Labor and Social Affaires). The coordination activity of

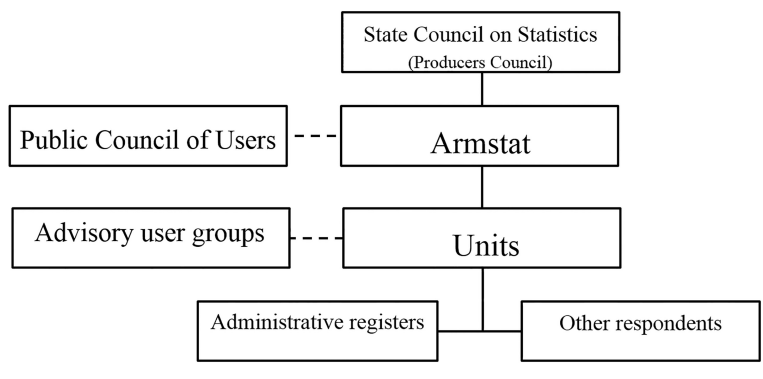

Fig. 3. Scheme of organizational, coordination and governance bodies in the Armenian NSS.

Armstat includes ensuring web dissemination platforms for all official statistics, and transmission to international organizations [9].

4) Sustainable Development Goals (SDGs)

To implement the UN 2030 Agenda, the National Reporting Platform (NRP) for statistics on SDGs plays an important role. The NRP is not only a tool for disseminating and reporting national statistics for the global SDGs indicators that provide the framework for monitoring progress towards SDGs, but also a key tool for enhancing coordination functions.

Armstat plays a key role within the national coordination system for the production of SDG indicators, contributes to strengthening inter-agency cooperation to meet the challenges of SDGs, supports measuring SDGs to achieve consistency in the work of national stakeholders, and facilitates information exchange and implementation of international methodology and standards. Armstat coordinates the production of data and metadata, the development of SDGs indicators tailored to the national context and new data sources and ensures appropriate mechanisms for data validation and quality.

\section{Other bodies of statistical governance in Armenia: The State Council on Statistics and the Public Council of Users}

The State Council on Statistics and the Public Council of Statistics are two important governance bodies in the Armenian NSS. However, this governance does not include the Central Bank of Armenia, which follows its respective legislation for the development, production and dissemination of official statistics, as already mentioned above.

Figure 3 gives a schematic overview on the organization, coordination and governance bodies in the Armenian NSS. 
The State Council on Statistics is the supreme body of governance of the NSS. The State Council on Statistics consists of seven members (including a Chairman), who are appointed by the Government of the Republic of Armenia for a six-year term. Members of the State Council on Statistics cannot be members of any political party, hold another public post or perform other paid work except for scientific, educational and creative work. In principle every citizen of Armenia can become a member of the State Council on Statistics, provided they:

- possess a thorough knowledge of the Armenian language;

- hold tertiary education;

- have worked for at least five years in macroeconomics and/or finances, demography and/or sociology, nature protection, international statistical cooperation or information technologies.

The President of Armstat as the Chief Statistician of Armenia holds also the post of the Chairman of the State Council.

The State Council approves the principles of the development, production and dissemination of Official Statistics and adopts legal acts in statistics, which are subject to mandatory implementation across the country. It also approves annual and five-year statistical programs and reports on their implementation.

In the Armenian statistical governance model shown in Fig. 3, the State Council on Statistics (the Managerial Board) is actually composed of producers of official statistics. In addition, there is a Public Council of Users of Official Statistics which represents the users of Official Statistics in Armenia.

The Public Council of Users of Official Statistics is the main advisory body to the State Council, to the President of Armstat and other producers of official statistics on issues of strategic importance for official statistics of Armenia. The Public Council consists of 11 members that are operating on a voluntary basis, representing users of different spheres (academic, public, private sector, etc.). Public sector representatives should not form a majority in the Public Council.

The President of Armstat is ex officio member of the Public Council.

The members of the Public Council, except the President of Armstat, are appointed and dismissed by the decision of the Prime Minister of Armenia, from recommendations by state bodies, the main users of official statistics - monetary, fiscal, economic, sociodemographic policy bodies, and other users of official statistics - scientific-educational institutions and nongovernmental organizations. ${ }^{2}$

The Public Council elects its chairperson from its members, who cannot be a representative of the state body.

The Public Council is granted with the following powers by law:

- makes proposals on the priority information needs of society in statistical programs, implementation of statistical programs and strategic development;

- provides advice on issues of compliance with the principles of official statistics;

- presents recommendations on statistical programs and opinions on reports of statistical program implementation.

The Public Council can organize discussions and give advice on the efficiency of cooperation within the NSS.

Other Advisory Bodies: The President of Armstat by the proposal of heads of subject-matter units may set up advisory units, consisting of the given unit and key users of that field of statistics for the purpose of strategic and methodological advisory support.

\section{Conclusions}

The National Statistical System of Armeinia is a relatively centralized system with the National Statistical Office, Armstat, as a coordinator in the center and a few other producers of Official Statistics, such as the Armenian Central Bank and some Ministries. Legislation and well-established procedures are in place for implementing the coordination role of the National Statistical Office, Armstat, within the NSS. The Central Bank of Armenia is also a producer of Official Statistics although - as is also often the case in international comparison - it follows a somewhat different legislation than the other producers of Official Statistics. Nevertheless, there exists an overall functioning coor-

\footnotetext{
${ }^{2}$ Members of the Public Council established by the Prime Minister Decree on 13 September 2019 are: The President of Armstat (ex officio), the Deputy Minister of Labor and Social Affairs, the Deputy Chairman of the State Revenue Committee, a Central Bank Board Member, the Head of Macroeconomic Policy Department of the Ministry of Finance, the Vice-rector of the State University of Economics of Armenia, the Vice-rector of the State Agrarian University of Armenia, the President of the Chamber of Commerce and Industry of Armenia, the Chair of the Association for Sustainable Human Development, the Chairman of the Association of Accountants and Auditors of Armenia and the Executive Director of "Armenpress", the Armenian news agency.
} 
dination of the NSS which relies on legal basis as well as on agreements such as Memoranda of Understanding (MoUs). In order to ensure relevance for the users of Official Statistics, different governance bodies have been installed in which Armstat is represented.

Although the NSS could be enlarged, some government authorities are not interested in becoming formally a producer of Official Statistics since they would have to follow the UN Fundamental Principles that requires additional work for them, as would the coordination with the National Statistical Office as the main coordinating body in the NSS.

\section{Acknowledgments}

We would like specially to thank Mr. Volker Täube for the detailed valuable comments on a draft version of this paper, as well as Mr. Steven Vale and Mr. Pieter Everaers for general comments.

\section{References}

[1] Generic Law on Official Statistics for Eastern Europe, Caucasus and Central Asia, UNECE, UNITED NATIONS, New York and Geneva, 2016. Available from: https://www.unece.org/index. php?id=45114.
[2] Scientific-programme, 62nd ISI World Statistics Congress, 18 23 August 2019, Kuala Lumpur, Malaysia. Available from: http://www.isi2019.org/scientific-programme-2/.

[3] Steve MacFeely. The continuing evolution of official statistics Some challenges and opportunities, Journal of Official Statistics 32(4), 2016.

[4] UN Fundamental Principles of Official Statistics, 29 January 2014. Available from: https://unstats.un.org/unsd/dnss/gp/fund principles.aspx.

[5] Guidance on Modernizing Statistical Legislation, UNECE, UNITED NATIONS, 2019. Available from: http://www.unece. org/index.php?id=51141.

[6] The ESS Vision 2020, European Statistical System. Available from: https://ec.europa.eu/eurostat/documents/10186/756730/ ESS-Vision-2020.pdf/8d97506b-b802-439e-9ea4-303e905f 4255.

[7] Law on Official Statistics of the Republic of Armenia. Available from: https://www.armstat.am/file/doc/99514643.pdf.

[8] European Statistics Code of Practice. Available from: https:// ec.europa.eu/eurostat/web/quality/european-statistics-code-ofpractice.

[9] Heinrich Bruengger. How Should a Modern National System of Official Statistics Look? The relationship between international principles on systems of official statistics and national statistical legislation, UNECE, 2008. Available from: https://www.unece. org/fileadmin/DAM/stats/documents/applyprinciples.e.pdf. 